\title{
PERANAN SYARA' DALAM PROSES ALIHPERAN KB MANDIRI DI KABUPATEN GOWA
}

\section{H. Abdul Kadir Ahmad}

\section{LATAR BELAKANG}

Penelitian ini dilakukan di tiga kecamatan dalam Kabupaten Gowa, masingmasing Kecamatan Sombaopu, Pallangga dan Bontonompo. Kecamatan yang disebutkan pertama merupakan wilayah kota sesuai dengan posisinya sebagai ibukota kabupaten dan berbatasan langsung dengan kotamadya Ujung Pandang; sementara dua kecamatan lainnya termasuk wilayah pedesaan. Namun demikian, polarisasi ini tidaklah ekstrim secara kultural, sebab sulit untuk memberikan pembatasan antara "kota" dan "desa" ketika proses transfonnasi budaya berjalan hampir secara masal di kawasan manapun pada era moderen sekarang ini.

Yang pasti adalah bahwa ketiga daerah tersebut dan penduduk Kab. Gowa pada umumnya -- tergolong dalam etnis Makassar dengan latar belakang budaya "siri" yang kental. Banyak kasus penganiayaan dan atau pembunuhan terjadi sebagai akibat dari pelanggaran "siri" tersebut. Biasanya "siri" dikaitkan dengan "kehormatan pribadi dan keluarga yang perlu dijaga dan dipertahankan, lebih khusus lagi mengenai kehormatan wanita, "dengan cara apapun juga. Dalam kadarnya yang paling "enteng" siri -- atau siri-siri -diartikan dengan "malu". Orang yang tidak dapat membela kehomiatan keluarganya disebut "tau tena siri'na" (orang tak punya harga diri); sedangkan orang tebal muka disebut tau tena sirisirina.
Aspek lain yang menarik dari masyarakat ini adalah masih kuatnya bertahan lembaga tradisional, baik lembaga "adat" maupun lembaga "syara". Lembaga adat yang oleh masyarakat setempat disebut ada' adalah lembaga yang mengurusi soal-soal pemerintahan; sementara lembaga syara' yang mengurusi bidang keagamaan dalam masyarakat. Keduanya morupakan dwitunggal (bali empo) dalam sistem administrasi pemerintahan, berjalan secara harmonis, apalagi sering terjadi pejabat dari kedua lembaga tersebut berasal dari latar belakang kerabat yang sama: keturunan Karaeng/daeng (bangsawan), dan "diwariskan" dari generasi ke generasi. Meski zaman sudah berubah, kecenderungan tersebut masih berjalan -- dalam kadar tertentu sampai sekarang.

Lembaga lain yang juga tidak kurang pentingnya dalam masyarakat setempat adalah "sanro" (dukun), baik dukun dalam arti umum, yaitu ahli pengobatan tradisional, maupun dukun beranak. Meski sudah ada dokter atau bidan, masyarakat tetap akrab dengan dukun. Salah satu sebabnya adalah karena dukun dianggap mampu mengakrabi (mendekati secara total) si pasicn, bagai hubungan scorang anak dan orang tua. Sering terjadi ketika seorang telah memeriksakan kandungannyakc dokter "berkonsultasi" lagi kepada seorang dukun perihal kandungannya - khususnya untuk membetulkan letak jabang bayi. 
Penggarabaran sepintas di atas, kecuali dapat memberikan petunjuk tentang inti budaya orang Gowa, khususnya daerah penelitian - juga orientasi sosialnya yang bersifat paternalistik, Peranan tokoh masyarakat, baik yang tergabung dalam lembagalembaga tersebut maupun tidak, sangat menentukan keberhasilan pembangunan.

\section{PROSPER PENGEMBANGAN KB MANDIRI}

Penelitian tentang Prospek pengembangan KB Mandiri dan peran yang diharapkan dari aparat syara' dilakukan dengan menggunakan metode (teknik) pengisian angket oleh Imam Desa/Lurah observasi dan wawancara mendalam. Di samping itu, untuk mendapatkan informasi yang relatif lebih lengkap dan intens dilakukan Focus Group Discussion, khususnya di Kecamatan Bontonompo. Penetapan kecamatan tersebut sebagai tempat diskusi, selain karena alasan teknis, juga karena Bontonompo merupakan daerah "satelit" Gowa yang relatif kuat memegang tradisi.

Ada empat unsur yang menghadiri diskusi tersebut - dilaksanakan tgl. 11 Desember 1990 di Kantor KUA Kec. Bontonompo - yaitu (1) Kepala Kua dan staf, (2) Para Imam Desa, (3) Dokter Puskesmas, dan (4) petugas KB tingkat kecama$\tan$ Bt.Nompo. Jumlah semuanya +20 orang.

Dari diskusi tersebut, dan yang ternyata tidak berbeda dengan hasil wawancara di kecamatan lain - terungkap beberapa masalah dasar pengembangan KB di Kec. Bontonompo, tetapi juga faktor-faktor pen- dukung. Termasuk dalam faktorpendukung adalah:

(1) Baik pandangan para aparat KUA dan Imam Desa terhadap hukum KB dan pandangan masyarakat tentang KB mcnurut mereka sudah bukan masalah lagi. KB dapat diterima dan bahkan sudah dipratekkan secaraumum dalam masyarakat, meski terbatas pada kontrasepsi konvensional (PIL).

(2) Bahwa kesadaran masyarakat Ber-KB sudah cukup tinggi, berkat keterlibatan berbagai pihak dalam ikut serta memberikan motivasi, tidak ketinggalan aparat syara'.

Hampir semua forum dimanfaatkan oleh mereka untuk "mengkampanyekan" KB, terutama khutbah nikah, khutbah Jum'at dan Majlis Ta'lim. Ada Majlis Ta'lim yang dilakukan setiap hari Senin dan Kamis khusus untuk ibu-ibu, merupakan program yang juga dimasukkan soal KB.

Namun demikian berbagai masalah juga masih mengganjal pelaksanaan KB, khususnya program $\mathrm{KB}$ mandiri dan peningkatan mutu keikutsertaan dalam KB melalui pemasangan alat kontrasepsi efcktif terpilih. Masalah-masalah tersebut antara lain adalah :

(1) Masih kurang diterimanya alat kontrasepsi efektif seperti IUD, apalagi tubektomi dan vasektomi. Apalagi, dua terakhir ini, menurut para imam, belum/ tidak dibolehkan oleh agama, kecuali dalam situasi darurat. Sedangkan IUD cenderung mengalami kemandegan terutama dikaitkan dengan sikap malu ibu-ibu jika kclaminnya dilihat orang

No. 5 \& 6 Th. III Januari / Juli 1992 
lain, selain suaminya sendiri; juga tabu dilihat oleh sesama wanita, kecuali dalam keadaan sangat terpaksa. Sedangkan aparat syara' "keberatan" kalau IUD dipasang oleh laki-laki. Kecuali sikap malu (siri-siri), juga banyak wanita merasa "ngeri" bahwa ada barang tersimpan di dalam rahim. Ini menurut informasi dan dokter Puskesmas. Menunit dokter tersebut, peran suami juga turut menentukan keputusan isteri untuk memasang alat kontrasepsi, temiasuk IUD. Sering terjadi, seorang ibu sudah siap (ingin) dipasangi IUD, akan tetapi setelah berkonsultasi dengan suaminya, lalu tidak disetujui oleh pihak suami.

Sebenarnya aparat syara' melihat tidak ada masalah lagi soal IUD dilihat dari pandangan agama. Karena itu Kepala KUA dapat mentolerir isterinya memasang IUD. Kiranya sikap malu dan ngerilah yang membuat mereka enggan beralih ke alat yang satu ini.

(2) Banyak peserta diskusi yang menyoroti kualitas dan kuantitas informasi yang diterima oleh PUS. Pengalaman dokter Puskesmas misalnya, menunjukkan banyak terjadi ketika petugas (Tim) dokter sudah siap memasangi ibu-ibu dengan IUD, lalu mereka hilang satu persatu, padahal mereka datang khusus untuk itu. Ini membuktikan bahwa informasi yang mereka terima tidak lengkap, atau menurut istilah dokter tersebut "mereka tidak tahu mau dibikin apa", setelah tahu mereka lalu menghilang. Karena itu, menurut peserta diskusi, hendaknya ibu-ibu jangan merasa diarak dalam ketidak tahuannya. Pengalaman peserta diskusi juga terungkap bahwa kebanyakan laki-laki (maksudnya suami) tidak merasa berkepentingan untuk mengikuti program KB. Konotasi KB adalah perempuan. Karena itu jarang terjadi bahwa para suami juga menjadi sasaran penerangan tentang KB. Hal ini juga merupakan kekurangan bagi pihak BKKBN dalam melakukanpendekatan.

(3) Banyak aparat syara' yang merasa kesulitan untuk memberikan penerangan kepada masyarakat tentang KB secara komplit. Mereka tahu KB secara sepotong-potong, dan selalu dikonotasikan dengan pengaturan kelahiran anak guna mencapai kesejahteraan. Mereka tidak mampu memberikan penjelasan secukupnya, terutama ketika sampai pada persoalan teknis. Dalam kedudukannya sebagai tokoh masyarakat dan tokoh agama di desa, para aparat syara' sering dan bahkan sangat kurang yang mampu menjelaskan macam-macam alat kontrasepsi dan prinsip pemakaiannya serta efektifitasnya masing-masing. Padahal jika saja mereka dapat memberikan penjelasan kepada masyarakat perihal karakteristik setiap alat kontrasepsi, misanya Alat Kontrasepsi Efektif Terpilih (AKET) hasil yang diharapkan akan lebih baik, mengingat dengan kedudukan mereka yang memiliki tingkat intensitas pertcmuan yang tinggi dengan masyarakat.

Untuk itu, disarankan kiranya aparat syara' dapat dibekali dengan pengetahuan yang cukup tentang KB secara 
keseluruhan, dan pengetahuan minimal tentang teknik pemasangan, prinsipprinsip kerja dan efektifitas setiap alat kontrasepsi, melalui pendidikan/Penataran atau Orientasi KIE. Dengan demikian, mereka diharapkan dapat memberikan penjelasan secara relatif sempurnakepadamasyarakat. Demikian pula diharapkan dukungan sarana informasi yang cukup, seperti brosur-brosur, buku-buku tentang KB, khususnya menurut tinjauan Islam.

Karena banyak di antara para imam desa merupakan produk pendidikan tradisional, yang menguasai aksara lontara, lebih dari bahasa Indonesia, maka disarankan buku/buku/brosur-brosur penerangan KB yang tertulis dalam lontara Makassar (Bahasa Daerah).

Ada kesan bagi para aparat syara' bahwa keterlibatan mereka atau mereka dilibatkan belum secara maksimal. Bahkan terhadap sesuatu yang dilihat dari sudut pandangan agama masih dipertanyakan tidak dikonsultasikan terlebih dahulu oleh pihak Petugas KB dan instansi terkait (sep. dokter), mi-salnya dalam hal pasektomi, dan tubektomi. Padahal, menurut mereka, cara seperti itu merugikan ummat, karena masih dipertanyakan kebolehannya. Begitu pula IUD yang dipasang oleh laki-laki. Sehingga kalau timbul reaksi dalam masyarakat terhadap program $\mathrm{KB}$, tumpuannya sering dihadapkan pada mereka (aparat syara') untuk menanganinya.

Mereka juga mempertanyakan pola/ pendekatan yang cenderung me- maksakan/menggiring masyarakat untuk ber KB atau memasang salah satu alat kontrasepsi yang diinginkan dari BKKBN.

Kasus-kasus seperti itu berkibat banyaknya calon yang tidak jadi memasang atau mengalami drop-out.

(4) Pandangan aparat syara' dan masyarakat menu rut aparat syara' tentang KB khususnya alat kontrasepsi tidak ada perbedaan yang menojol. Semua peserta diskusi dan aparat syarat'lain yang diwawancarai dirumah/kantormengakui bahwa masyarakat pada umumnya memiliki pehatian yang cukup terhadap gerakan KB. Demikian pula pandangan mereka baik aparat syarat-syarat, maupunmasyarakat menurut menurut aparat syara' lain yang diwawancarai di rumah/kantor - mengakui bahwa masyarakat pada umumnya memiliki perhatian yang cukup terhadap gerakan KB. Demikian pula pandangan mereka - baik aparat syara', maupun masyarakat menurut aparat syara' -tentang alat kontrasepsi, tingkat penerimaannya tergantung tingkat kepekaan alat tersebut dilihat dari sudut budaya siri-siri (malu). Ini terbukti bahwa metode kontrasepsi yang tidak berkaitan langsung secara teknis dengan alat kelamin dapat diterima dan lebih banyak dipraktekkan, seperti pil, suntikan, dan susuk. Sedangkan metode kontrasepsi yang berhubungan langsung dengan alat kelamin wanita atau lakilaki cenderung kurang atau tidak disetujui. Hal ini tampak pada sikap mereka terhadap alat kontrasepsi IUD, 
obat vaginal, kondom dan kontap, dan lebih-lebih lagi vasektomi dan tubektomi.

(5) Sikap seperti disebutkan di atas cenderung mempengaruhi sikap mereka terhadap Program Alih kontrasepsi kepada MKET (Metode Kontrasepsi EfektifTerpadu), yangternyatamemang hasilnya masih sangat kurang. Mereka menyarankan agar aparat pelaksana program KB bcrsabar dan tidak terlalu menekan -- apalagi memaksakan -pcnggunaan alat yang disebut efektif, kalau memang masyarakat belum menerimanya. Syukur kalau mereka sudah menerim a KB, dengan alat apapun yang mereka pakai, Ujar Kepala KUA Bt. Nompo. Bahkan, kalau perlu, menurut mereka, bukan hanya alat-alat kontrasepsi yang ada sekarang yang diprogramkan - yang datang dari atas tetapi juga KB yang oleh banyak pasangan dalam masyarakat tradisional, dipraktekkan, misalnya dengan menggunakan ramuan atau tcknik tradisional : KB alam.

(6) Menurut mereka, adalah sudah waktunya aparat KB memanfaatkan lembaga-lembaga tradisional secara optimal tidak setengah-tengah - dalam menangani program KB, menuju alih peran KB Mandiri. Fungsi syara' ternyata sangat strategis untuk itu, terutama jika dikaitkan dengan kcdudukan mereka dalam masyarakat. Dan untuk itu, mereka menyatakan siap membantu sepenuhnya sepanjang tidak mengganggu pckerjaannya sebagai pegawai syara'. Bahkan isteri-isteri mereka sudah terlibat dalam program KB meski masih passif (pemakai).

Meski demikian, masih banyak di antara mereka yang kurang setuju dengan program $\mathrm{KB}$ mandiri, dalam arti KB mandiri penuh. Menurut mereka masyarakat kita sudah berada pada tingkat pra-mandiri sampai mandiri parsial. Masalahnya, sebelum sampai kepada KB mandiri penuh, masih perlu diupayakan agar program KB ini dapat merata dalam praktek, meski dalam tingkat pcrsctujuan sudah tidak ada masalah. Pegawai negeri ^ekalipun masih banyak yang tidak mempraktekkan, meski mereka tidak juga menentang, ujar salah scorang peserta. Karena itu salah satu tugas KUA dan aparatnya, khususnya di bidang Pendais, adalah menyempatkan "kampanye KB setiap pertemuan guru-guru.

Salah satu wadah yang mereka nilai dapat mempercepat proses alih program KB mandiri adalah melalui pembentukan kclompok-kelompok pengajian ibu-ibu, yang dirangkaikan dengan arisan. Dengan kelompok ini, selain dapat menjadi wadah pengembangan program alih pemakaian Metode Kontrasepsi Efektif Terpilih, juga dapat dikembangkan teknik pcnanggulangan biaya/ongkos pembelian alat kontrasepsi menuju KB Mandiri.

Sayang sekali padatempat lokasi penelitian belum muncul organisasi-organisasi keagamaan, seperti NU, Muhammadiyah, MDI dsb, yang memotivasi masyarakat melalui kelompok-kelompok pengajian/majlis ta'lim. 
Para dukun juga disarankan oleh peserta diskusi untuk dijadikan "sarana" mativator dalam menyukseskan program KB. Kalau perlu, menurut mereka, dukun-dukun itu dididik agar bisa memasangi pasiennya spiral. Hal ini, tentu saja ditolak oleh dokter, yang mengatakan bahwa untuk memasang spiral dibutuhkanteknis medis yang sulit dilakukan selain dokter. Akan tetapi bahwa para dukun beranak dapat dijadikan motivator KB adalah tepat, mengingat mereka sangat dekat dengan masyarakat, terutama ibu-ibu, kata dokter Puskesmas itu. Untuk itu tidak ada salahnya jika mereka diberikan pengetahuan tentang alat-alat kontrasepsi sebagaimana juga yang dituntut seorang aparat syara'. Kesempatan untuk menyarankan seorang ibu yang sedang melahirkan untuk memakai salah satu alat kontrasepsi dapat dilakukan oleh dukun, dan timingnya tepat. Dan pada waktu yang sama, ia (dukun) dapat memanggil dokter untuk langsung memasangi ibu tersebut dengan spiral (IUD), yang menurut dokter, waktu paling tepat untuk memasang spiral adalah minggu pertama setelah ibu melahirkan. "Karena organnya masih longgar", ketus dokter berkelakar.

(7) Salah satu gagasan yang muncul dalam diskusi itu adalahperlunyadimanfaatkan lembaga desa, seperti LKMD, LMD, dalam rangka penanganan dan pengembangan KB mandiri. Hal ini dapat dilakukan dengan misalnya melakukan pengumpulan dana melalui iuran sukarela dalam bentuk semi koperasi, kemudian uang yang terkumpul dapat dimanfaatkan untuk membiayai pembelian alat-alat kontrasepsi.

\section{PENUTUP}

Saya' memiliki fungsi strategis untuk dikembangkan sebagai wadah transformator program $\mathrm{KB}$, dan penanganan $\mathrm{KB}$ dalam upaya mengantisipasi KB Mandiri. Hal itu dikaitkan dengan fungsi mereka dalam masyarakat, sebagai pelayan pada hampir semua kegiatan yang berkaitan dengan siklus kehidupan, mulai dari liang rahim sampai ke liang kubur. Peran strategis mereka di desa sampai sekarang masih tetap tampak, dan dominan di antara lembaga-lembaga tradisional lainnya.

Untuk mengoptimalkan peran mereka dalam alih peran KB mandiri, diperlukan langkah-langkah konkret untuk membenahi dan mem bekali mereka dengan pengetahuan yang cukup di bidang KB baik secara umum maupun secara khusus (teknis); agar dapat memberikan informasi yang lengkap kepada masyarakat.

Secara politis, sebagai bagian dari program nasional, baik para aparat syara' maupun masyarakat (menurut mereka) memandang KB tidak ada masalah dilihat dari segi agama. Namun demikian terhadap alat kontrasepsi atau metode tertentu, seperti IUD, vasektomi/tubektomi, obat vaginal, kondom, cenderung diabaikan, selain karena faktor siri (malu), juga karena masih diragukan hukumnya dari scgi agama. Untuk ini, perlu pendekatan khusus. KB Mandiri dipahami sebagai sudah memasuki tahap Mandiri Parsial, tetapi untuk 
Mandiri penuh masih dibutuhkan waktu, sampai masyarakat tidak mengalami trauma (persepsi yang salah) tentang KB secara keseluruhan, hanya karena kesalahan pendekatan. PeneranganKB dari pihak yang berwenang (petugas KB) perlu ditingkatkan, baik kuantitas maupun kualitasnya, sampai masyarakat mengerti dengan baik, dan tidak salah kaprah terhadap alat kontrasepsi tertentu' selain itu juga agar mereka tidak merasa digiring untuk menerima alat kontrasepsi tertentu.

Pengembangan majlis ta'lim/kelompokkelompok pengajian dapat dijadikan salah satu forum strategis untuk proses penerimaan dan pengembangan KB Mandiri oleh masyarakat, baik diprakarsai oleh aparat syara', maupun olehorganisasikeagamaan.* 